\title{
Funding of human stem cell research by the United States
}

\author{
Phillip B.C. Jones \\ Senior Patent Attorney, Patent Department, ZymoGenetics Inc. \\ 1201 Eastlake Ave., East, Seattle, WA 98102 \\ Voice: (206) 442-6681 \\ Fax: (206) 442-6678 \\ E mail:pbcj@wolfenet.com
}

Keywords: Abortion, Embryonic, Human embryo, Human fetal tissue

During the fall of 1998, three research groups announced that they had devised methods for obtaining human embryonic stem cells. Human stem cells are characterized by the ability to form many cell types, and the scientific community anticipates that the cells should be useful for the treatment of a wide variety of diseases. The dilemma is that human stem cell methodology can require, at least to some extent, research with human fetal tissue or research involving human embryos. Those opposed to federal funding of the former are concerned that the studies would support the "legitimacy" of abortion, while the latter is seen as prohibited under current law. The National Bioethics Advisory Committee has suggested that the federal government should fund both activities.

\section{Federal funding of human stem cell research: The nature of the problem}

\section{The ban on human embryo research in the United States}

"Current law on live fetal and embryonic research is no mere political compromise."

Richard Doerflinger, Associate Director for Policy Development at the Secretariat for Pro-Life Activities with the National Conference of Catholic Bishops (Doerflinger, 1998)

In 1979, under pressure from anti-abortion groups, the Health and Human Services Department disbanded an advisory board that reviewed federally funded research on human sperm, eggs, and embryos (Smith, 1989). Reflecting strong anti-abortion sentiments, Ronald Reagan and later, George Bush, blocked federal funding for all research on human embryos (Kleiner, 1994a).

Thirteen years after the advisory board was eliminated, President Clinton announced that he would lift the ban on embryo research, and he gave the National Institutes of Health (NIH) the task of drafting guidelines for studies in this field (Kleiner, 1994b). In 1994, the NIH established the Human Embryo Research Panel to develop policies for methods that researchers should use to obtain embryos, and to determine the scope of ethical embryo research (Green, 1995). The panel consisted of 19 scientists, physicians, ethicists, lawyers, and community representatives (Green, 1995).

In November 1994, after ten months of deliberations, the Human Embryo Research Panel presented its guidelines for human embryo research (Kleiner, 1994a; "Report," 1994; Fletcher, 1995). According to the panel, research should be allowed only if the embryos were less than 14 days old, if the studies could not be performed with animal embryos, and only if scientists could demonstrate a compelling reason why the studies should be performed. The panel also decided that researchers should not be limited to surplus embryos from in vitro fertilization procedures, and that researchers could create embryos in vitro for research purposes. However, the researchers would have to show that their work with newly created embryos promised outstanding scientific and therapeutic value. The panel also warned that women should not be paid for donating their eggs for research.

During the following month, the NIH voted to adopt the guidelines ("House Panel," 1995). However, on the day of the vote, President Clinton issued an Executive Order that government funded scientists would not be allowed to create human embryos for research (Clinton, 1994; Kleiner, 1994b; "House Panel," 1995). There is some speculation that this announcement was influenced by the recent Republican victory in Congressional elections (Kleiner, 1994b). President Clinton also promised to establis h a National Bioethics Advisory Commission to "ensure that advice on complex ethical issues that affect our society can continue to be developed" (Clinton, 1994).

As a result of the President's announcement, researchers could only use embryos that remained after in vitro fertilization treatments. Still, some found this restriction to be insufficient. Congressman Robert Dornan (R-CA) promised to introduce legislation to prevent federal funding for any human embryo research (Kleiner, 1994b). 
In July 1995, under pressure from anti-abortion groups, the House Appropriations Committee approved a proposal offered by Representatives Jay Dickey (R-AR) and Roger Wicker (R-MS) to ban the use of federal funds for research using human embryos ("House Panel," 1995; Appel, 1995). To implement the new prohibition, the Committee added an amendment to the $1996 \mathrm{NIH}$ appropriation bill, which stated that federal funds may not be used for the creation of a human embryo for research purposes or for research in which a human embryo is destroyed, discarded, or knowingly subjected to risk of injury or death that would be greater than the risk allowed for research on fetuses in utero (Green, 1995; Congr. Rec., 1996; Kreeger, 1997). Thus, the amendment reflected an endorsement of the existing ban on embryo creation, and additionally barred federal funding for any research requiring embryos obtained from in vitro fertilization procedures.

In January 1996, President Clinton signed a continuing resolution to keep the federal government open, despite a lack of consensus on the budget (Annas et al., 1996; Wadman, 1996). The resolution included the prohibition against the use of federal funds for research on human embryos (Annas et al., 1996).

During the following years, Congress continued to attach a ban on funding of human embryo research in a rider to the Health and Human Services appropriations legislation (Seachrist, 1999b). In its Fiscal Year 1998 appropriations act directive, Congress amended the appropriations rider to include an expanded definition of "human embryo" as follows:

(a) None of the funds made available in this Act may be used for --

(1) the creation of a human embryo or embryos for research purposes; or

(2) research in which a human embryo or embryos are destroyed, discarded, or knowingly subjected to risk of injury or death greater than that allowed for research on fetuses in utero under 45 CFR 46.208(a)(2) and section 498(b) of the Public Health Service Act (42 U.S.C. $289 \mathrm{~g}(\mathrm{~b}))$.

(b) For purposes of this section, the term "human embryo or embryos" include any organism, not protected as a human subject under 45 CFR 46 as of the date of the enactment of this Act, that is derived by fertilization, parthenogenesis, cloning, or any other means from one or more human gametes or human diploid cells. (Departments of Labor, Health and Human Services, and Education, and Related Agencies Appropriations Act of 1998, § 513).

However, three announcements during the fall of 1998 raised concerns about whether even this more restrictive ban would be adequate.

\section{Cultured human stem cells: a new controversy}

On November 5, 1998, Geron Corporation (Menlo Park, CA) announced that it had supported two research teams, who had discovered ways to derive cultured human embryonic stem cells and human pluripotent stem cells ("First derivation," 1998; "PNAS reports," 1998). James A. Thomson, an associate research veterinarian at the University of Wisconsin's Regional Primate Research Center (Madison, WI), led one research team that derived stem cells from human embryonic tissue. Thomson's group began by obtaining fresh or frozen cleavage stage human embryos, which had been donated with consent by participants in in vitro fertilization programs (Thomson, 1998). Thomson and his colleagues cultured the embryos to blastocyst stage, and then, isolated the blastocyst inner cell masses to derive the stem cells. Measurement of cell surface markers and enzyme activities indicated that the cells were embryonic stem cells. Moreover, the cells retained the ability to form a variety of cell types, including gut epithelium, cartilage, bone, smooth muscle, striated muscle, neural epithelium, embryonic ganglia, and squamous epithelium.

The second research team, lead by John D. Gearhart, a professor of gynecology and obstetrics at Johns Hopkins University School of Medicine (Baltimore, MD), devised a method for establishing human pluripotent stem cell lines (Shamblott et al., 1998). The researchers derived their cells from primordial germ cells of five- to nine-week postfertilization embryos or fetuses, which were the product of therapeutic terminations of pregnancy. Characterization of the human primordial germ cell-derived line demonstrated that the cells met the criteria for pluripotent stem cells, closely resembling embryonic germ cells.

Geron has explained that the research activities of the groups did not fall within the ban on embryo research, because the experiments neither created nor destroyed embryos (Brower, 1999). Thomson's group derived their cell line from the cells of 15 - to 20- cell pre-embryos, which give rise to both placental tissue and the developing embryo (Pedersen, 1999; Wertz, 1999a). Gearhart's group obtained their cell line from germ cells of aborted fetuses. Germ cells are precursors of eggs and sperm, and, like blastocyst cells, are pluripotent (Pedersen, 1999; Wertz, 1999a).

In light of the fact that researchers had been trying to grow stem cells outside the body for years, the successes of Thomson, Gearhart, and their colleagues were met with great acclaim from the scientific community (Brower, 1999; Langreth, 1998). On the other hand, the fact that the research of both groups appeared to involve, in some way, fetal or embryonic cells raised ethical and legal concerns. On the day of Geron's press release, lawyers at the National Institutes of Health (NIH; Bethesda, MD) began to review the laws on embryo research to determine whether the government could fund studies on the stem cell lines (Brower, 1999; Langreth, 1998). 
An alternative method for obtaining stem cells seemed to avoid the embryo research controversy, but still managed to create an uproar. On November 12, 1998, Advanced Cell Technology, Inc. (Worcester, MA) announced that its scientists had developed a method for producing primitive human embryonic stem cells by fusing a human somatic cell with a bovine egg that lacked a nucleus ("Advanced Cell," 1998). The company indicated that the technique may provide an unlimited supply of stem cells for transplant medicine (“Advanced Cell," 1998). The scientific community criticized the characterization of the cells as either human or stem cells, because the company's researchers had not performed routine characterization tests, such as searching for human protein expression (Marshall, 1998b).

The scientific community also viewed Advanced Cell Technology's announcement with some skepticism, because the company chose to release the news about their unpublished two-year old experiment within one week of the Thomson and Gearhart announcements (Marshall, 1998b). Michael West, Advanced Cell Technology's president and CEO, explained that he did not feel comfortable moving ahead with the technology before getting an idea about how U.S. regulations would affect the field. By publicizing the old experiment, West hoped that the National Bioethics Advisory Commission (NBAC) would help to make this clear (Marshall, 1998b).

Advanced Cell Technology's announcement did attract attention, particularly because the company's researchers had created their cells using a nuclear transfer technique similar to the one used to clone Dolly the sheep (Marshall, 1998b). As one commentator remarked, Advanced Cell Technology's experiment "stirs visions of mermaids, minotaurs, and other half-human creatures" (Seachrist, 1998a, p. 1). In response to Advanced Cell Technology's announcement, President Clinton wrote a letter to NBAC, stating that he was "'deeply troubled by this news of experiments involving the mingling of human and nonhuman species," and he requested that NBAC consider the ethical implications during their next meeting ("Statement by the press secretary," 1998). In the meantime, Senator Arlen Spector (R-PA) and Senator Tom Harkin (D-IA) called a Senate hearing to determine whether federal dollars should support research on stem cells (Weiss, 1998; Fox, 1999).

At this point, the human stem cell studies had been privately funded. Thomson had carefully severed his own research from any federally supported research by setting up a separate laboratory from the one used to perform NIHfunded studies (Marshall, 1998a). The equipment and personnel in the second laboratory were funded privately by Geron Corporation (Menlo Park, CA) and the Wisconsin Alumni Research Foundation. Geron also supported Gearhart's research, while Advanced Cell Technology's research was based on private funding. The congressional ban had indeed pushed embryonic cell research into the private sector.

The fact that privately funded scientists can perform embryonic cell research does not trivialize the question of federal funding. Public opinion matters to a company, and the federal law governing NIH research does provide a standard for other U.S. researchers. Accordingly, Thomas Okarma, Geron's vice president of research, made it clear that the present "law itself states that funding cannot be given to research that creates or destroys embryos; the research of Drs. Thomson and Gearhart did neither" (Brower, 1999, p. 140). In addition, a private company can afford to spend only a limited amount of funds for basic research, because the focus is on application.

\section{Should the United States government support human stem cell research?}

\section{The case against federal funding}

The argument against the federal funding of human embryonic stem cell research tends to be terse. A position paper from The Center for Bioethics and Human Dignity explains the core argument:

Human embryos are not mere biological tissues or clusters of cells; they are the tiniest of human beings. Thus, we have a moral responsibility not to deliberately harm them. (The Center for Bioethics and Human Dignity, 1999, paragraph 10).

That is, the human embryo has the same moral status as a live human baby (McGinley and Fawcett, 1999).

From this perspective, Richard Doerflinger, has warned that funding stem cell research "would forge new ground for active government support of research that takes human life" (McGinley and Fawcett, 1999, paragraph 6). Doerflinger has emphasized that this governmental action "violates human experimentation norms because it destroys one member of the human family to help another" (McGinley and Fawcett, 1999, paragraph 6).

Often, arguments against federal funding weave in the Nuremberg war crimes trials, which creates very powerful imagery (Kass, 1999). These trials led to the formulation of ethical principles considered to provide the foundation of bioethics (Jonsen, 1998). According to the Nuremberg Code, voluntary consent of a human subject is absolutely essential (Jonsen, 1998). This is problematic if the subject is an embryo.

Perhaps in recognition of the value of human stem cell research, opponents of federal funding have suggested alternative sources for the cells. For example, Richard Doerflinger suggested that cells from spontaneous abortions and ectopic pregnancies may prove to be useful (Doerflinger, 1998). 
Last January, Bjornson and colleagues published a report, which demonstrated that specialized stem cells in adult tissues can give rise to a variety of other cell types (Bjornson et al., 1999). Funding opponents, who promoted this use of adult stem cells, urged that there was no longer any need to extract stem cells from human embryos. In addition, they pointed out that using adult stem cells would also resolve the problem of tissue rejection that is inherent in embryonic stem cell therapy (Cong. Rec., 1999; Doerflinger, 1999; Wadman, 1999b; Wertz, 1999b).

In sum, opponents of federal funding for embryonic stem cell research take the position that legislators should not make a moral decision on behalf of all taxpayers to subsidize human experimentation (Seachrist, 1998b). Opposition exists to any research that relies upon embryonic cells, and this includes research on cells harvested from frozen embryos (Russo, 1999). The Advanced Cell Technology method, which utilizes adult human cells, is also not deemed acceptable. Richard Doerflinger (1998) has explained that the relevant question about the Advanced Cell Technology approach is whether the new hybrid cell with a human nucleus begins, even for a brief time, to grow and to develop as an early human life form. If this is the case, then this technique requires the creation and destruction of human embryos.

\section{The case for federal funding}

\section{(a) Human stem cell research has significant therapeutic potential}

A major component of the argument for federal funding of human embryonic stem cell research is that such research may provide a large number of new therapies for human disease. Shamblott et al. noted that the most important property of their pluripotent stem cells is the ability to differentiate in vitro into ectodermal, endodermal, and mesodermal derivatives. With these properties in mind, the researchers stated that:

Human pluripotent stem cells, with their potential to differentiate into a wide variety of cell types in culture, would be invaluable for studies of some aspects of human embryogenesis and for transplantation therapies. They may serve to define the culture conditions and differential gene expression necessary for cell-type-specific differentiation and for the isolation of lineage-restricted stem cells that could serve as a source of cells for transplantation. Genetic modification of these pluripotent stem cells may allow the generation of universal donor cells or cells that have been customized to meet individual requirements. Clearly, these goals warrant investigations on the isolation, study, and use of human pluripotent stem cells. (Shamblott et al., p. 13730).

In a report of preliminary findings and recommendations for human stem cell research, the American Association for the Advancement of Science (AAAS) and the Institute for Civil Society (ICS) commented on the credibility of stem cell-based transplantation therapy:

There already exists evidence from animal studies that stem cells can be made to differentiate into cells of choice, and that these cells will act properly in their transplanted environment. In human beings, transplants of hematopoietic stem cells (the cells which eventually produce blood) following treatments for cancer, for example, have been done for years now. Further, somewhat cruder experiments (e.g., the transplantation of fetal tissue into the brains of Parkinson's patients) indicate that the expectation that stem cell therapies could provide robust treatments for many human diseases is a reasonable one. It is only through controlled scientific research that the true promise will be understood. (AAAS and ICS, 1999a, paragraph 4).

Proponents of federal funding for human stem cell research have suggested that therapies may be developed for Parkinson's disease, Alzheimer's disease, Huntington disease, spinal cord injury, damage due to stroke, arthritis, diabetes, muscular dystrophies, degenerative heart disease, and damage from burns (Gearhart, 1998; West, 1998; Thomas, 1998; Fox, 1999; Melton, 1999). Moreover, some have suggested that new drugs could be tested with a human cell line developed to mimic a disease process, as an alternative to the use of an animal model of human disease to evaluate safety and efficacy of a candidate drug (Varmus, 1998). In this way, human stem cells would be used to screen drugs for potential side effects in an effort to streamline the drug discovery process (Seachrist, 1998b).

If even a fraction of this potential can be realized, then a question arises about whether it is ethical to shun human stem cell research. Arthur Caplan, a University of Pennsylvania bioethicist, observed that tens of thousands of spare embryos, scheduled for eventual destruction, are currently frozen in the United States (Seachrist, 1998b). He questioned the morality of refusing to use these tissues to perform research that may cure a person suffering from a debilitating disease or injury, and he urged that "[w]e should not hold that person hostage to the [sic] our concern about these tissues that are going to be destroyed anyway" (Seachrist, 1998b, p. 3). Referring to these spare embryos, Joseph Bailey, who has amyotrophic lateral sclerosis, observed that "[n]o life will ever come of these sources, except perhaps mine and more than 100 million other Americans suffering from fatal and chronic diseases" (McGinley and Fawcett, 1999, paragraph 19).

\section{(b) Federal funding would enhance prospects for realizing therapeutic potential}

Studies have documented that government-funded basic research provides an important foundation for innovation by the biotechnology and pharmaceutical industries (Feldbaum, 1999). Moreover, federal funding creates collaborations between federal and private sectors 
(Feldbaum, 1999). In Thomson's view:

How soon such therapies will be developed will depend on whether there is public support of research in this area. Private companies will have an important role in bringing new [embryonic stem] cell-related therapeutics to the marketplace; however, the current ban in the U.S. on the use of Federal funding for human embryo research discourages the majority of the best US researchers from advancing this promising area of medical research. (Thomson, 1998, paragraph 3).

Although one can debate the notion that the best researchers work in the public sector, the important point is that early basic research is often under-funded by the private sector. The federal government is the only realistic source for funds required to support a large and sustained investment in basic research (Seachrist, 1998b; AAAS and ICS, 1999a; Fox, 1999).

Proponents for federal funding have also expressed concern that restricting human stem cell research to the private sector would result in a corporate monopoly on the new therapeutic techniques, and a lack of public review (Weiss, 1998; McGee, 1999). Arthur Caplan has suggested that, in the absence of federal support, "[n]ot only will progress be slow, it will be hidden” (Weiss, 1998, paragraph 11).

\section{Approaches to resolving the Issue about federal support}

\section{The view of the NIH}

On January 15, 1999, Harriet S. Rabb, general counsel for Health and Human Services, provided Harold Varmus with her conclusions about the scope of the current embryo research ban (H. S. Rabb, personal communication, January 15, 1999; Seachrist, 1999a). In brief, she indicated that, since human pluripotent stem cells are not a human embryo, the statutory prohibition on the use of funds appropriated to the Department of Health and Human Services for human embryo research would not apply to research on pluripotent stem cells.

With this legal opinion in hand, Varmus announced that he decided to move forward with funding research on newly derived human embryonic stem cells (Seachrist, 1999a). At the same time, he warned that the NIH still could not fund research to produce the cells (Seachrist, 1999a). The Clinton administration backed the policy that federal funds could be used for research on human embryonic stem cells obtained from the private sector (Marshall, 1999).

Opponents to federal funding did not embrace this policy as a reasonable resolution to the issue. Seventy members of the House of Representatives wrote a letter of protest to Donna E. Shalala, the Secretary of Health and Human Services, stating that present law bars the use of tax dollars to fund research that relies upon the destruction of a human embryo or an injury to a human embryo (Wadman, 1999a ). Jay Dickey (R-AR) agreed that the ban was intended to cover research that depends upon the removal of cells from embryos, if that action kills the embryo (Wadman, 1999a). Richard Doerflinger opined that the NIH policy contradicted the plain language of the appropriations rider, and that Congress could have drafted the rider to specifically forbid only the destruction and discarding of embryos, if Congress had intended such a narrow prohibition (Doerflinger, 1999).

Rabb's interpretation of the phrase "research in which a human embryo or embryos are destroyed, discarded" does seem reasonable. To turn Doerflinger's argument around, if Congress had intended to forbid support for any research that ultimately required the destruction of an embryo, then Congress could have clearly stated this intent.

Regardless of the interpretation of the appropriations rider, the NIH policy does not resolve the underlying issues about human embryonic stem cell research. The NIH will probably find it necessary to resolve the moral discrepancies posed by a policy that permits taxpayersupported human stem cell research, as long as the "dirty work" of obtaining the cells is left to the private sector.

\section{Findings and recommendations of the AAAS and ICS}

During August 1999, The American Association for the Advancement of Science (AAAS) and the Institute for Civil Society (ICS) published their preliminary findings and recommendations regarding stem cell research and its applications (AAAS and ICS, 1999a). This was followed by a final report published in November (AAAS and ICS, 1999b).

The AAAS and the ICS support public and private research on human stem cells derived from adult, fetal, and embryonic sources. At the same time, the groups recommend strengthening federally and privately funded research to study potential alternative sources and methods for obtaining stem cells. However, they do not recommend public funding for activities involved in the isolation of embryonic stem cells. Like the NIH, therefore, the AAAS and ICS distinguish between research on stem cells and the act of obtaining stem cells. The AAAS and ICS predict that this exclusion will not have a significant negative impact on the progress of research, because there should be sufficient material from the private sector for the foreseeable future.

Presumably turning to the private sector, the AAAS and ICS support the harvest of embryonic stem cells from embryos that remain after an infertility procedure. As a prerequisite to such harvesting, an embryo's progenitors must have provided full and informed consent for the use of embryos in research. The AAAS and ICS suggest that 
policies on embryo procurement should include the following points:

(1) Women should not undergo extra cycles of ovulation and retrieval in order to produce more "spare" embryos in the hope that some of them might eventually be donated for research;

(2) Analogous with our current practice for organ donation, there should be a solid "wall" between personnel working with the woman or couple who hope to become pregnant, and personnel requesting embryos for stem cell purpose;

(3) Women and men, as individuals or as couples, should not be paid to produce embryos, nor should they receive reduced fees for their infertility procedures for doing so; and

(4) All reasonable efforts should be made to obtain the consent of both gamete donors (AAAS and ICS, 1999b, p. 18).

As the two groups note, these aspects are consistent with existing ethical research practices.

In sum, the AAAS and ICS have proposed a position that is similar to NIH policy, and should be useful in the interim. They also acknowledge that the issue of stem cell procurement must be addressed. Significantly, the AAAS and ICS have taken the view that stem cell research does not raise unique ethical or policy issues, and that these issues can be managed adequately by existing structures and policies.

\section{Recommendations of the NBAC}

In September 1999, the National Bioethics Advisory Commission (NBAC) released a report of their conclusions on the ethical approach to human stem cell research (NBAC, 1999). At the outset, NBAC noted that human stem cells can be derived from four sources. Human stem cells can arise from human fetal tissue, obtained after an elective abortion (the embryonic germ cells of the Gearhart group). As Thomson's group demonstrated, human stem cells can be derived from human embryos that are created during an in vitro fertilization process, and that are no longer needed by the progenitors who were treated for infertility. Human stem cells can also be obtained from human embryos created by in vitro fertilization techniques for the express purpose of obtaining embryonic stem cells. Finally, the Advanced Cell Technologies group showed that human stem cells can be derived from human or hybrid embryos that are generated by a cloning technique (e.g., somatic cell nuclear transfer), in which the nucleus of an adult human cell is inserted into an enucleated human or animal ovum. In passing, NBAC also noted that, although stem cells may be obtained from adult tissues, studies indicate that this approach will be scientifically and technically limited.

NBAC acknowledged that a principle ethical justification for public funding of human stem cell research is that these studies may produce therapies for individuals suffering from serious, and often fatal, disease. In light of these potential benefits, NBAC recommended that research involving the derivation and use of human embryonic germ cells from cadaveric fetal tissue should continue to be eligible for federal funding. The Commission noted that the removal of fetal germ cells does not require the destruction of a live fetus, and that fetal tissue is not intentionally created for stem cell research. NBAC also recommended that federal funding should be available for research involving the derivation and use of human embryonic stem from embryos remaining after infertility procedures. An implementation of this recommendation would require an amendment of the current ban on embryo research. The Commission viewed this ban as conflicting with the ethical goals of pursuing social benefits and avoiding or ameliorating potential harm.

Significantly, NBAC took the position that it is ethically acceptable for the federal government to finance research involving either the derivation or the use of embryonic stem cells. Thus, unlike the NIH and AAAS-ICS analyses, NBAC decided that, from the point of view of federal funding eligibility, there is no ethical distinction between these activities. In the Commission's view, researchers will derive substantial scientific benefits from a detailed understanding of the process of embryonic stem cell derivation, and that it will be important to be able to repeatedly derive embryonic stem cell cultures, because the cells are not stable indefinitely in culture. Therefore, there are practical reasons for allowing federally funded researchers to obtain new stem cells.

NBAC did not recommend federal support for research requiring embryos created solely for research, using in vitro fertilization techniques. There is no compelling reason for funding this type of research at this time, NBAC stated, in view of the supply of cadaveric fetal tissue and embryos remaining after infertility treatment.

According to NBAC, the federal government also should not support research involving the derivation or use of human embryonic stem cells from embryos created by somatic cell nuclear transfer into oocytes. Here, the reasoning is that the technique has the potential of creating a human embryo. At the same time, NBAC appears to encourage an exploration of the methodology by the private sector.

The NBAC report recommended procedures for providing voluntary and informed consent to potential donors of cadaveric fetal tissue and embryos for research purposes, and NBAC urged that embryos and cadaveric fetal tissue should not be bought or sold. Finally, NBAC recommended that the Department of Health and Human Services should establish a National Stem Cell Oversight and Review Panel to ensure that federally funded research conforms with the report's guidelines. As a practical matter, NBAC suggested that any protocols involving the derivation of human embryonic stem cells and human 
embryonic germ cells should be reviewed by a local, institutional review body before consideration by the national panel.

With regard to the private sector, NBAC proposed that sponsors of research that would have been eligible for federal funding should voluntarily adopt the applicable recommendations of the report. NBAC recognized that privately funded programs might also involve research that is not eligible for federal funding. For these cases, the NBAC report suggested that professional societies and trade associations should develop ethical guidelines consistent with the general principle of the report, and that private research sponsors should voluntarily comply with such guidelines.

\section{Concluding remarks}

There appears to be no disagreement that human stem cell research has the potential to provide new therapies. Indeed, Science magazine recently designated stem cell research as "1999's breakthrough of the year" (Vogel, 1999a). The challenge, therefore, is to identify the means that society will tolerate to achieve these potential results. Such tolerance varies according to the source of human stem cells. One clear message is that the federal government will not fund studies requiring the creation of a human embryo for the express purpose of research.

At the other extreme of acceptability, at least one opponent to federal support has suggested that researchers could obtain biological material from ectopic pregnancies and spontaneous abortions (Doerflinger, 1998). This suggestion raises the question about why these sources should be considered ethically acceptable. A characteristic shared by an embryo or fetus resulting from an ectopic pregnancy or a spontaneous abortion is that the embryo or fetus is not destined to develop into a living human. If this is the rationale for promoting these sources, then the same acceptability should be bestowed upon frozen embryos of in vitro fertilization clinics, which are considered spare and fated for destruction.

There are practical problems with relying upon ectopic pregnancies and spontaneous abortions to supply tissue. Studies indicate that more than half of ectopic pregnancies resolve spontaneously (Pisarka et al., 1998). In addition, medical, not surgical, treatment has become the primary treatment in many facilities, and when surgery is necessary, the process can destroy the "product of conception" (Pisarka et al., 1998). With regard to obtaining tissue from a spontaneous abortion, it should be clear that reliance upon a spontaneously occurring event is problematic.

Opponents of federal funding appear to have embraced adult stem cell technology, an approach that avoids the embryo research controversy and allows researchers to obtain full and informed consent from the cell donor. The downside of this approach is that it might not work:
Adult stem cells, obtained from mature tissues, differentiate into a narrower range of cell types. As a result, many cells of medical interest cannot currently be obtained from adultderived stem cells. It is also less feasible to develop largescale cultures from adult stem cells. (AAAS and ICS, 1999a, paragraph 20).

As discussed above, NBAC also concluded that adult stem cells do not appear very promising at this time.

Advance Cell Technology's researchers have devised an alternative method for creating stem cell cultures, which, at least superficially, appears to avoid issues regarding embryo research. Richard Doerflinger (1998) has noted, however, that there may be such an issue here:

Oddly, defenders of such an experiment must simultaneously argue that it is promising because it can produce genetically matched, fully human tissue for transplantation -- and that it is not covered by the ban on embryo research because fusing a human nucleus and a cow egg does not really produce a human embryo. (paragraph 26).

It is unclear at this time whether the Advance Cell Technology method produces a human embryo, whether the hybrid cells are truly stem cells, and whether the hybrid cells would provide the basis for therapy. NBAC, which has taken a generally progressive posture on human stem cell funding, has suggested that the federal government should not support the Advance Cell Technology approach. This would seem to be a politically appropriate decision, considering that the hybrid cells are produced by the same basic method associated with the human cloning controversy. The value and nature of the human hybrid cells will probably be characterized by the private sector or by researchers who reside outside of the United States.

In the Gearhart approach, stem cell cultures can be derived from tissue obtained following a therapeutic abortion. There would seem to be merit in a technique that creates value from fetal tissue that is otherwise slated for disposal. Moreover, the United States Supreme Court has made it clear that the State's interest in the fetus, up to the point of viability, is not strong enough to justify a prohibition of abortion (Roe v. Wade, 1973; Planned Parenthood of Southeastern Pa. v. Casey, 1992). Nevertheless, some have voiced the concern that federal funding of Gearhart's approach would "legitimize abortion" (Doerflinger, 1998; McGee, 1999). Abortion remains a politically defining issue.

In addition to the controversy about abortion, a recent study casts doubt on the notion that embryonic germ cells obtained from aborted fetal tissue provide an adequate substitute for stem cells extracted from an embryo (Steghaus-Kovac, 1999). An experiment with mice showed that mouse embryonic stem cells implanted into early mouse embryos cause an abnormal development of tissues 
that contain the cells (Steghaus-Kovac, 1999). The researchers suggested that the genes in the embryonic germ cells lack modifications required for normal development (Steghaus-Kovac, 1999). It is presently unclear whether human embryonic germ cells have the same type deficiency as their mouse counterparts.

At this time, the last source for human stem cells is the frozen spare embryo of in vitro fertilization programs. This also seems to be the best source for obtaining therapeutically useful cells. However, the embryos have been a center of controversy, because opinions vary about the moral status of the embryos. NBAC observed that, although "most would agree that human embryos deserve respect as a form of human life, disagreements arise regarding both what form such respect should take and what level of protection is required at different stages of embryonic development" (NBAC, 1999, p. ii).

Over 25 years ago, the United States Supreme Court avoided a dilemma that is inherent in the frozen embryo controversy:

We need not resolve the difficult question of when life begins. When those trained in the respective disciplines of medicine, philosophy, and theology are unable to arrive at any consensus, the judiciary, at this point in the development of man's knowledge, is not in a position to speculate as to the answer. (Roe v. Wade, 1973, p. 159).

That "difficult question" is the linchpin to resolving the conflict between a commitment to protect human life and a commitment to cure disease with embryonic stem cell methodology.

One perspective is that human life begins with the fertilized ovum. As discussed above, this belief is expressed by opponents to federal support for research involving frozen embryos. The other viewpoints are that human life begins at birth, or that human life begins sometime between fertilization and birth. Proponents of federal support have often expressed the latter view, which engenders the need to identify the crucial event in human embryonic development.

During the 1980's, there was a tempestuous debate about embryo research in the United Kingdom, which gave rise to the Human Fertilisation and Embryology Act of 1990 (Mulkay, 1997). One underlying premise of the Act is that the human embryo undergoes a fundamental change in status around day 14, and that after this time, the embryo should be considered a human individual, which must not be used for experimental purposes. As noted above, the 1994 NIH panel also pointed to this 14-day milestone. The 14-day theory is also consistent with biological observations, which indicate that there is no reason to believe that a multicellular biologically integrated human individual exists from fertilization to about 16 days in embryonic development (Jones, 1986).
Human embryos may be frozen at the prezygote stage, the two- to eight-cell stage, or the blastocyst stage (Sparks, 1998). The blastocyst stage, which is the latest of these stages, is typically reached six to seven days after oocyte insemination (Sparks, 1998). Accordingly, there is a rationale for supporting federal funding of stem cell research with spare frozen embryos, which fall within the 14-day window. This is a position that NBAC advocates.

The NBAC report also recognizes that there may be a distinction, but not a meaningful difference, between the act of obtaining cells from a blastocyst and the act of studying those cells. It is duplicitous to promote the latter, while disregarding the morality of the former. If the federal government supports research on human embryonic stem cells, then it must permit researchers to derive the cells from blastocyts.

The NIH, however, continues to cling to such distinctions. In its draft guidelines for research on human pluripotent stem cells, the NIH explains how to qualify for funding of stem cell research, while asserting that the derivation of the stem cells from early human embryos is ineligible for federal funding (Varmus, 1999). Even this conservative approach has inspired attack, and anti-abortion activists have promised to get Congress to block support for all embryonic stem cell research (Vogel, 1999b).

It remains to be seen whether the decision to provide federal support for any activity that requires frozen embryos will be informed by a thorough discussion of various viewpoints. In the end, it may be that the mere balance of political power will determine the answer.

\section{References}

Advanced Cell Technology announces use of nuclear transfer technology for successful generation of human embryonic stem cells. (1998, November 12). Available: http://www.advancedcell.com

American Association for the Advancement of Science and Institute for Civil Society. (1999a, August 18). Stem cell research and applications: Preliminary findings and recommendations. Available: http://www.aaas.org

American Association for the Advancement of Science and Institute for Civil Society. (1999b, November ). Stem cell research and applications: Monitoring the frontiers of biomedical research. Available: http://www.aaas.org

Annas, G. J., Caplan, A., and Elias, S. (1996, May 16). The politics of human-embryo research - - avoiding ethical gridlock. The New England Journal of Medicine 334:13291332.

Appel, A. (1995, July 27). Embryo research faces a renewed ban in US. Nature 376:288. 
Bjornson, C. R. R., Rietze, R. L., Reynolds, B. A., Magli, M. C., and Vescovi, A. L. (1999, January 22). Turning brain into blood: A hematopoietic fate adopted by adult neural stem cells in vivo. Science 283:534-537.

Brower, V. (1999, February). Human ES cells: can you build a business around them? Nature Biotechnology $17: 139-142$.

Clinton, W. J. (1994, December 2). Statement by the President. Available: http://www.pub.whitehouse.gov

142 Cong. Rec. S429 (daily ed. January 26, 1996) (statement of Senator Smith).

145 Cong. Rec. E1696 (daily ed. July 29, 1999) (statement of Representative Schafer).

Departments of Labor, Health and Human Services, and Education, and Related Agencies Appropriations Act of 1998, Pub. L. 105-78, § 513, 111 Stat. 1467, 1517 (1997).

Doerflinger, R. M. (1998, December 2). Testimony before the Senate appropriations subcommittee on Labor, Health and Human Services, Education and related agencies. Available: http://www.senate.gov

Doerflinger, R. M. (1999, January 26). Testimony before the Senate appropriations subcommittee on Labor, Health and Human Services, Education hearing on legal status of embryonic stem cell research. Available: http://www.senate.gov

Feldbaum, C.B. (1999, March 22). BIO response to NBAC on stem cell research. Available: http://www.bio.org

First derivation of human embryonic stem cells reported in Science. (1998, November 5). Available: http://www.geron.com

Fletcher, J.C. (1995, July). US public policy on embryo research: Two steps forward, one large step back. Human Reproduction 10:1875-1878.

Fox, J. L. (1999, January). Stem cell hearing stirs bioethics debate. Nature Biotechnology 17:11.

Gearhart, J. (1998, December 2). Testimony before the Senate appropriations subcommittee on Labor, Health and Human Services, Education regarding stem cell research. Available: http://www.senate.gov

Green, R. M. (1995, August 16). The ban on embryo research hurts U.S. health. Newsday, A34.

House panel approves many restrictions in spending bill for health agency. (1995, July 28). Contemporary Women's Issues Database. 14:5-6. Available: Electric Library.
Jones, H. W., Jr. (1986). Ethical Issues in in vitro fertilization. In: In vitro fertilization - Norfolk. H. W. Jones, Jr., G. S. Jones, G. D. Hodgen, and Z. Rosenwaks (Eds.). Baltimore, MD, Williams \& Wilkins, pp. 295-301.

Jonsen, A. R. (1998). The birth of bioethics. New York, Oxford University Press.

Kass, J. (1999, July 1). Research debate tackles new world some dare not brave. Available: Chicago Tribune.

Kleiner, K. (1994a, October 8). US to sanction embryo research. New Scientist 144:5.

Kleiner, K. (1994b, December 24). Clinton Uturn on embryo research. New Scientist 144:6.

Kreeger, K. Y. (1997, March 17). Reproduction research held back by diffuse rules, charged politics. The Scientist $11: 1,6$.

Langreth, R. (1998, November 6). Lab takes important step in growing human tissue. Available: The Wall Street Journal Interactive Edition.

Marshall, E. (1998a, November 6). A versatile cell line raises scientific hopes, legal questions. Science 282:10141015.

Marshall, E. (1998b, November 20). Claim of human-cow embryo greeted with skepticism. Science 282:1390-1391.

Marshall, E. (1999, July 23). Ethicists back stem cell research, White House treads cautiously. Science 285:502.

McGee, G. (1999, May 24). Stem cells: The goo of life, the debate of the century. Available: http://www.msnbc.com

McGinley, L. and Fawcett, A. (1999, June 21). Research supporters, abortion foes clash over research on stem cells. Available: The Wall Street Journal Interactive Edition.

Melton, D. (1999, January 12). Testimony before the Senate appropriations subcommittee on Labor, Health and Human Services, Education regarding stem cell research. Available: http://www.senate.gov

Mulkay, M. (1997). The emb ryo research debate: Science and the politics of reproduction. Cambridge, England, Cambridge University Press.

National Bioethics Advisory Commission. (1999, September). Ethical issues in human stem cell research, Vol. I, Report and recommendations of the National Bioethics Advisory Commission. Rockville, MD, National Bioethics Advisory Commission.

Pedersen, R. A. (1999, April). Embryonic stem cells for 
medicine. Scientific American 280:68-73.

Pisarska, M. D., Carson, S. A., and Buster, J. E. (1998, April 11). Ectopic pregnancy. The Lancet 351:1115-1120.

Planned Parenthood of Southeastern Pa. v. Casey, 505 U.S. 833 (1992).

PNAS reports derivation of human pluripotent stem cells from cultured primordial germ cells. (1998, November 5). Available: http://www.geron.com

Report of the Human Embryo Research Panel. (September 27, 1994). Rockville, MD, National Institutes of Health.

Roe v. Wade, 410 U.S. 113 (1973).

Russo, E. (1999, January 4). Hearing sets stage for stem cell funding debate. The Scientist 13:3.

Seachrist, L. (1998a, November 13). Human embryonic stem cells made by bovine egg fusion. BioWorld Today $9: 1,2$.

Seachrist, L. (1998b, December 3). Embryo stem-cell research debated in Senate sub-panel. BioWorld Today 9:1, 3.

Seachrist, L. (1999a, January 20). Varmus: NIH plans to fund embryo stem-cell research. BioWorld Today 10:1, 4.

Seachrist, L. (1999b, January 21). Ethicists to tackle human stem cell research. BioWorld Today 10:1, 6.

Shamblott, M. J., Axelman, J., Wang, S., Bugg, E. M., Littlefield, J. W., Donovan, P. J., Blumenthal, P. D., Huggins, G. R., and Gearhart, J. D. (1998, November 10). Derivation of pluripotent stem cells from cultured human primordial germ cells. Proceedings of the National Academy of Science 95:13726-13731.

Smith, E.T. (1989, December 11). Will Washington resume funding embryo research? Business Week, 127.

Sparks, A. E. T. (1998). Human embryo cryopreservation: Benefits and adverse consequences. In: Stored tissue samples: Ethical, legal, and public policy implications. R. F. Weir (Ed.). Iowa City: University of Iowa Press, pp. 6681.

Statement by the press secretary. (1998, November 21). Available: http://www.whitehouse.gov

Steghaus-Kovac, S. (1999, October 1). Ethical loophole closing up for stem cell researchers. Science 286:31.

Thomson, J. A., Itskovitz-Eldor, J., Shapiro, S. S., Waknitz, M. A., Swiergiel, J. J., Marshall, V. S., and Jones, J. M.
(1998, November 6). Embryonic stem cells derived from human blastocysts. Science 282:1145-1147.

The Center for Bioethics and Human Dignity. (1999). On human embryos and stem cell research: An appeal for legally and ethically responsible science and public policy. Available: http://www.stemcellresearch.org

Thomson, J. A. (1998, December 2). Testimony before the Senate appropriations subcommittee on Labor, Health and Human Services, Education regarding stem cell research. Available: http://www.senate.gov

Varmus, H. (1998, December 2). Testimony before the Senate appropriations subcommittee on Labor, Health and Human Services, Education regarding stem cell research. Available: http://www.senate.gov

Varmus, H. (1999, December 2). Draft National Institutes of Health Guidelines for research involving human pluripotent stem cells. Federal Register 64:67576-67579.

Vogel, G. (1999a, December 17). Breakthrough of the year: Capturing the promise of youth. Science 286:2238-2239.

Vogel, G. (1999b, December 10). NIH sets rules for funding embryonic stem cell research. Science 286:20502051.

Wadman, M. (1996, February 1). Embryo research barred from federal funds. Nature 379:386.

Wadman, M. (1999a, February 25). Congress may block stem-cell research. Nature 397:639.

Wadman, M. (1999b, April 15). NIH stem-cell guidelines face stormy ride. Nature 398:551.

Weiss, R. (1998, December 3). Ban on "stem cell" testing reviewed. Washington Post, A02.

Wertz, D. C. (1999a, February). Human embryonic stem cells: a source of organ transplants. The Gene Letter 3(2). Available: http://www.geneletter.org

Wertz, D. C. (1999b, February). A new source of stem cells: One's own body. The Gene Letter. 3(2). Available: http://www.geneletter.org

West, M.D. (1998, December 2). Testimony before the Senate appropriations subcommittee on Labor, Health and Human Services, Education regarding stem cell research. Available: http://www.senate.gov 